\title{
Human Neutrophil Elastase Modulates Platelet Function by Limited Proteolysis of Membrane Glycoproteins
}

\author{
Mark S. Brower, Richard I. Levin, and Kimberly Garry \\ Division of Hematology-Oncology, Department of Medicine and the Specialized Center for Research in Thrombosis, \\ The New York Hospital-Cornell Medical Center, New York 10021, and the Division of Cardiology. \\ Department of Medicine, New York University School of Medicine, New York 10016
}

\begin{abstract}
During blood coagulation human polymorphonuclear leukocytes release elastase in amounts that can exceed $100 \mathrm{nmol} / \mathrm{liter}$. We therefore studied the effect of elastase on platelet structure and function. Physiologic concentrations of elastase specifically inhibited thrombin-induced platelet aggregation and ristocetininduced agglutination of washed platelets in a time- and dosedependent manner. This was associated with a decrease in the number of high affinity thrombin binding sites on the platelet surface (analysis by "Ligand" program) from 31 per platelet to 12 per platelet $(P<0.05)$. As analyzed by sodium dodecyl sulfate-polyacrylamide gel electrophoresis, treatment of ${ }^{3} \mathbf{H}$ labeled platelets with elastase resulted in a decrease in the percent glycoprotein at $130,000-150,000 M_{\mathrm{r}}=$ and an increase in the percent protein at $M_{\mathrm{r}}=102,000$. The supernatant from elastase-treated platelets contained a $M_{r}=88,000$ glycoprotein not found in the supernatant from untreated platelets. Immunoprecipitation studies with monoclonal antiglycoprotein Ib demonstrated that treatment of whole platelets with physiologic concentrations of elastase resulted in proteolytic cleavage of glycoprotein Ib. Elastase treatment of glycoprotein immunoisolated with monoclonal antiglycoprotein Ib antibody resulted in formation of a glycopeptide with the same electrophoretic mobility as the $M_{\mathrm{r}}=102,000$ membrane-related glycopeptide. In contrast, analysis by Western blot technique using antiglycoprotein IIb and IIIa antibodies demonstrated that elastase did not degrade glycoproteins IIb or IIIa.

We conclude that elastase inhibition of thrombin-induced platelet stimulation is accompanied by $(a)$ a reduction in the number of thrombin binding sites per platelet and $(b)$ proteolysis of glycoprotein Ib.
\end{abstract}

\section{Introduction}

Human polymorphonuclear leukocyte (PMN) $)^{1}$ elastase is the major neutral protease released by human PMN during blood

This study was presented in part at the Annual Meeting of the American Society for Clinical Investigation, Washington DC, 1983, and appeared in abstract form (1983). Clin. Res. 31:483.

Dr. Brower is the recipient of a William S. Paley Fellowship in Academic Medicine. Address correspondence to Dr. Brower, Cornell University Medical College.

Received for publication 4 June 1984 and in revised form 15 October 1984.

1. Abbreviations used in this paper: DTT, dithiothreitol; GPA, tosyl-GlyL-Pro-L-Arg-paranitroanalide; PBS, phosphate-buffered saline, $100 \mathrm{mM}$

J. Clin. Invest.

(c) The American Society for Clinical Investigation, Inc.

0021-9738/85/02/0657/10 $\$ 1.00$

Volume 75, February 1985, 657-666 coagulation, or activation by soluble immune complexes, $\mathrm{C} 5 \mathrm{a}$, or endotoxin (1-3). Elastase is released into the circulation in acute leukemia and in septicemia (4). Several studies have indicated that the decrease in the concentration of coagulation factors seen in these conditions may be the result of direct proteolysis by leukocyte elastase (5). Leukocyte elastase also inactivates human antithrombin III (6), $\alpha_{2}$-plasmin inhibitor, and $\mathrm{C} \overline{1}$ inactivator (7). In circulating blood leukocyte elastase is inactivated mainly by $\alpha_{1}$-antitrypsin (8); however, this inhibitor is readily inactivated by oxidizing agents such as those generated by phagocytosing $\operatorname{PMN}(9,10)$.

Several studies suggest a potential role for neutrophils in the modulation of hemostasis and thrombosis. Arterial thrombi are characterized by the presence of large numbers of PMN lining the perimeter of platelet aggregates (11-13). Marcus et al. (14) and Maclouf et al. (15) have documented that plateletderived arachidonate or 12-hydroperoxy-eicosatetraenoic acid stimulates the biosynthesis of PMN 5,12-dihydroxyeicosatetraenoic acid. This suggests that platelet-derived arachidonate may serve as a precursor for the PMN-derived eicosanoid leukotriene $B_{4}$, a powerful chemoattractant and secretagogue (15-17). Additionally, platelet factor 4, a cationic protein liberated by platelets during the release reaction, has been demonstrated to stimulate PMN elastase activity against elastin (18-20).

The present report details studies on the effect of human leukocyte elastase on platelet structure and function. Our findings indicate that physiologic concentrations of elastase specifically inhibit thrombin-induced platelet aggregation and serotonin release as well as ristocetin-induced platelet agglutination. Loss of thrombin responsiveness is accompanied by a reduction in the number of high affinity thrombin binding sites per platelet and by elastase-mediated proteolysis of platelet membrane glycoprotein Ib.

\section{Methods}

Human PMN elastase. Human PMN elastase was purified from outdated leukocyte concentrates as described $(3,7)$. The concentration of elastase was determined by its extinction coefficient of 9.85 (21). The purified elastase demonstrated one protein-staining band when analyzed by SDS-polyacrylamide gel electrophoresis (PAGE) following reduction with dithiothreitol (DTT) (22). The specific activity of the elastase was $92 \%$ by active site titration using the titrant Ac-Ala-AlaAnval-ONp (a gift of Dr. J. Powers, Georgia Institute of Technology, Atlanta, GA) as described by Powers and Gupton (23).

Alpha-1-antitrypsin. $\alpha_{1}$-Antitrypsin was purified from plasma as

$\mathrm{NaCl}, 38 \mathrm{mM} \mathrm{Na}_{2} \mathrm{HPO}_{4}, 12.5 \mathrm{mM} \mathrm{NaH}_{2} \mathrm{PO}_{4}, \mathrm{pH} \mathrm{7.4;} \mathrm{PBS-Triton,}$ PBS containing $0.5 \%$ (vol/vol) Triton $\mathrm{X}-100,0.02 \% \mathrm{NaN}_{3}, 0.1 \%$ bovine serum albumin; PBS-Tween, PBS containing $0.5 \%$ (vol/vol) Tween 20; PAGE, polyacrylamide gel electrophoresis; PMN, polymorphonuclear leukocyte; PRP, platelet-rich plasma; Tris, $0.1 \mathrm{M}$ Tris- $\mathrm{HCl}$, $1.25 \mathrm{mM} \mathrm{CaCl}_{2}, \mathrm{pH} 8.3$. 
previously described and its concentration determined by its extinction coefficient of 5.3 (24). The final inhibitor preparation was free of other contaminating plasma protease inhibitors as analyzed by double diffusion in agarose gels with specific antibodies against $\alpha_{2}$-macroglobulin, $\mathrm{C} \overline{1}$ inactivator, antithrombin-III, inter- $\alpha$-trypsin inhibitor, or chymotrypsin inhibitor obtained from Calbiochem-Behring Corp., La Jolla, CA.

Platelet aggregation studies. Platelet-rich plasma (PRP) and washed platelet suspensions were prepared by the technique of Mustard et al. (25) as modified by Weksler et al. $(26,27)$. Platelet aggregation studies were performed at $37^{\circ} \mathrm{C}$ with $0.4-\mathrm{ml}$ aliquots of PRP or washed platelets $\left(2 \times 10^{8} / \mathrm{ml}\right)$ stirred at $1,000 \mathrm{rpm}$. Platelet aggregation was performed in a Payton 600BD dual-channel aggregometer (Payton Assoc., Scarborough, Ontario, Canada) and recorded with a Soltec 1242 (Sun Valley, CA) dual channel strip chart recorder (28). Aggregation was tested with threshold doses of the following agents (expressed as final concentration in the cuvette): sodium arachidonate (Nu Chek Prep, Elysian Fields, MN), 0.25 mM; ADP (Sigma Chemical Co., St. Louis, MO), $8 \mu \mathrm{M}$; fibrillar bovine collagen (Hormon-Chemie, Munich, Federal Republic of Germany), $2 \mu \mathrm{g} / \mathrm{ml}$; thrombin (the generous gift of Dr. John W. Fenton III, New York State Department of Health, Albany, NY); epinephrine (Parke Davis Co., New York), $5 \mu \mathrm{g} / \mathrm{ml}$. Washed platelets $\left(2 \times 10^{8} / \mathrm{ml}\right)$ were agglutinated with Ristocetin (Sigma Chemical Co.) 0.5 to $1.0 \mathrm{mg} / \mathrm{ml}$ plus VIII:VWF (Hemophil [Hyland Div., Travenol Laboratories, Inc., Costa Mesa, CA]; 0.1 to $0.2 \mu \mathrm{g} / \mathrm{ml}$ ).

The threshold stimulus determined for individual platelet preparations was defined as the lowest concentration that caused a $90 \%$ or greater increase in light transmission at $5 \mathrm{~min}$ when added to stirred platelets at $37^{\circ} \mathrm{C}(28)$. Elastase inhibition of aggregation by the above agents was tested by adding various concentrations of elastase to platelets for various times at $37^{\circ} \mathrm{C}$. After inhibiting elastase with $\alpha_{1}$ antitrypsin ( $\alpha_{1}$-antitrypsin:elastase molar ratio 5:1), a previously determined threshold dose of the aggregating agent was added, and aggregation was recorded.

Thrombin-induced secretion of $\left[{ }^{14} \mathrm{C}\right]$ serotonin by platelets. This was measured by standard technique $(27,29)$. Before elastase treatment, at least $80 \%$ of total $\left[{ }^{14} \mathrm{C}\right]$ serotonin was released from platelets upon stimulation with high concentrations of thrombin $(\geq 100 \mathrm{nM})$.

Labeling of ${ }^{125}$ I-thrombin. $\alpha$-Thrombin was labeled with ${ }^{125} I$ by the method of Martin et al. (30). Titration of ${ }^{125}$ I-thrombin with tosylglycyl-L-proline-L-arginine-paranitroanalide (GPA, Vega Fox Biochemicals, Tucson, AZ) was modified from the method of Kirchof et al. (31). GPA was dissolved in methanol $(14 \mathrm{mg} / \mathrm{ml})$ and diluted 10 -fold with Tris $0.1 \mathrm{M}, \mathrm{CaCl}_{2} 1.25 \mathrm{mM}, \mathrm{pH} 8.3$ containing bovine serum albumin $1 \mathrm{mg} / \mathrm{ml}$ (Tris buffer). Serial dilutions of ${ }^{125} \mathrm{I}-\alpha$-thrombin in Tris buffer $(0.15 \mathrm{ml})$ were mixed with GPA solution. Color development at $405 \mathrm{~nm}$ was followed at $10 \mathrm{~min}$ intervals in a Titertek Multiscan photometer (Flow Laboratories, Rockville, MD). The change in absorbance per minute in the thrombin-containing wells was subtracted from the values obtained in wells containing no thrombin. The change in absorbance per minute was used to calculate the concentrations of ${ }^{125}$ I-thrombin using a standard curve simultaneously generated by the serial dilution of unlabeled $\alpha$-thrombin, the concentration of which had been determined by active site titration with $p$-nitrophenyl- $p$ 'guanidinobenzoate- $\mathrm{HCl}(32)$. The specific radioactivity of the ${ }^{125} \mathrm{I}-$ thrombin was $\sim 5 \mathrm{Ci} / \mathrm{mmol}$.

Binding measurements. Measurement of ${ }^{125} \mathrm{I}$-thrombin binding to platelets was modified from the oil centrifugation method of Martin et al. (30). Whole human blood was added to tubes containing EDTA $100 \mathrm{mM}$ in $0.15 \mathrm{M}$ phosphate-buffered saline, $\mathrm{pH} 7.0$ (19:1 vol/vol) and centrifuged at $160 \mathrm{~g}$ for $15 \mathrm{~min}$ at $23^{\circ} \mathrm{C}$. The PRP was collected and centrifuged at $1,067 \mathrm{~g}$ for $15 \mathrm{~min}$. The sedimented platelets were resuspended in $15 \mathrm{ml}$ Tris- $\mathrm{HCl}(75 \mathrm{mM}), \mathrm{KCl}(100 \mathrm{mM})$, sodium citrate $(12 \mathrm{mM})$, and EDTA $(5 \mathrm{mM}) \mathrm{pH}$ 6.3. The platelets were washed twice more and resuspended in $\mathrm{NaCl} 136 \mathrm{mM}$, Tris- $\mathrm{HCl} 25$ $\mathrm{mM}$, glucose $5 \mathrm{mM}$, EDTA $1 \mathrm{mM}$, pH 7.4 containing $5 \mathrm{mg} / \mathrm{ml}$ bovine serum albumin (Sigma Chemical Co., essentially fatty acid free). Platelets $\left(1.5-7 \times 10^{8} / \mathrm{ml}\right)$ were equilibrated in this buffer for $10 \mathrm{~min}$ at $23^{\circ} \mathrm{C}$ before the addition of thrombin. Incubation with thrombin was for $10 \mathrm{~min}$ at $23^{\circ} \mathrm{C}$ unless otherwise specified. Platelets then were separated from buffer $(0.3 \mathrm{ml})$ by layering onto $0.5 \mathrm{ml}$ of a $6.7: 3.3$ mixture of Dow 550 (Dow Chemical Co., Midland, MI) and Dow 556 silicone oil (sp gr 1.040; Dexter Corp., Olean, NY) (33) and by centrifugation in a $1.5-\mathrm{ml}$ conical polypropylene centrifuge tube $(12,000$ $g$ for $2 \mathrm{~min}$ ) in an Eppendorf centrifuge. Two $0.1-\mathrm{ml}$ aliquots of the aqueous phase were transferred to counting vials. The tube was carefully inverted, drained, and the bottom of the tube containing the platelet pellet was sheared from the tube and counted in a Searle 1185 gamma counter (Searle Radiographics, Inc., Des Plaines, IL). The maximum binding of thrombin to platelets was reached within $5 \mathrm{~min}$ after addition of thrombin; binding remained maximum for at least $30 \mathrm{~min}$ after addition of thrombin. Of added $\left[{ }^{14} \mathrm{C}\right]$ sorbitol (Amersham Corp., Arlington Heights, IL), $<0.013 \%$ was trapped in the pellet. This would result in an error in the bound/free ratio of $<2 \%$ at the highest concentrations of thrombin, so that corrections were not made.

Data was analyzed with the "Ligand" program for fitting multiple binding sites data (Biomedical Computing Technology Information Center, Vanderbilt University, Nashville, TN) developed by Munson and Rodbard (34). The Ligand program was used to correct for nonspecific binding using both a one-site and two-site model.

${ }^{3} \mathrm{H}$-Labeling of platelet surface glycoproteins. Platelet surface glycoproteins were labeled with tritium by modification of established methods $(35,36)$. Washed platelets from $150 \mathrm{ml}$ of whole blood were resuspended at $0^{\circ} \mathrm{C}$ in $1.3 \mathrm{ml}$ of $137 \mathrm{mM} \mathrm{NaCl}, 2.7 \mathrm{mM} \mathrm{KCl}, 1.2$ $\mathrm{mM} \mathrm{NaHCO}, 0.4 \mathrm{mM} \mathrm{NaH}_{2} \mathrm{PO}_{4}, 1 \mathrm{mM} \mathrm{MgCl}_{2}, 2 \mathrm{mM} \mathrm{CaCl}, 0.1 \%$ glucose, $0.35 \%$ bovine serum albumin, $\mathrm{pH} 7.35$. Sodium metaperiodate $(2 \mathrm{mM}) 0.15 \mathrm{ml}$ was added to the platelet suspension prior to incubating in the dark for $10 \mathrm{~min}$ at $0^{\circ} \mathrm{C}$. The suspension was diluted with buffer, sedimented by centrifugation at $1,067 \mathrm{~g}$ for $10 \mathrm{~min}$ and washed once more. The platelets resuspended in $1.5 \mathrm{ml}$ buffer at $23^{\circ} \mathrm{C}$ were mixed with $2.5 \mathrm{mCi}\left[{ }^{3} \mathrm{H}\right] \mathrm{NaBH}_{4}$ (New England Nuclear, Boston, $\mathrm{MA})$ in $0.01 \mathrm{ml} \mathrm{NaOH}(0.01 \mathrm{M})$. After $30 \mathrm{~min}$, cold buffer $(25 \mathrm{ml})$ was added and the platelets centrifuged at $1,067 \mathrm{~g}$ for $10 \mathrm{~min}$. The platelets were resuspended, and centrifuged twice more. Aliquots were taken for study by aggregometry as detailed above.

Treatment of ${ }^{3} \mathrm{H}$-labeled platelets with elastase. The ${ }^{3} \mathrm{H}$-labeled platelet suspensions $\left(2 \times 10^{9}\right.$ platelets $\left./ \mathrm{ml}\right)$ were exposed to either elastase (0-300 nM) or to elastase buffer $(0.05 \mathrm{M}$ sodium acetate, 0.45 $\mathrm{M} \mathrm{NaCl}, \mathrm{pH} 5.5$ ) for various time intervals at $23^{\circ} \mathrm{C}$. $\alpha_{1}$-Antitrypsin was added to inhibit elastase ( $\alpha_{1}$-antitrypsin:elastase molar ratio $\geq 5$ : 1) and the platelets centrifuged at $1,067 \mathrm{~g}$ for $10 \mathrm{~min}$. Each supernatant was removed and the platelet pellet washed and resuspended in 0.05 $\mathrm{ml}$ buffer. Aliquots were taken for study by aggregometry as detailed above.

SDS-PAGE. Samples were mixed with an equal volume of $0.06 \mathrm{M}$ Tris- $\mathrm{HCl}, 2 \%$ SDS, $5 \%$ glycerol, $0.001 \%$ bromphenol blue, and $2 \%$ DTT; solubilized by heating at $10^{\circ} \mathrm{C}$ for $3 \mathrm{~min}$, and stored $\left(-70^{\circ} \mathrm{C}\right)$. SDS-slab gel electrophoresis was performed by the method of Laemmli (37) using a 3.8\% stacking gel and a 9\% separation gel. Gels were fixed in $25 \%$ isopropanol and $10 \%$ acetic acid prior to staining with Coomassie Blue $(0.1 \%)$ and radioautography (38). Densitometry was performed at $633 \mathrm{~nm}$ using an LKB Ultroscan Laser Densitomer (LKB Instruments, Inc., Rockville, MD) and a 2210 2-channel recorder.

Immunoenzymatic analysis of the effect of elastase on intact platelet glycoproteins IIb and IIIa. Platelets $\left(10^{10} / \mathrm{ml}\right)$ were treated with elastase (80 $\mathrm{nM})$ or buffer prior to the addition of $\alpha_{1}$-antitrypsin as detailed above. Following SDS-PAGE of unreduced samples ( $3 \mu \mathrm{g} / \mathrm{lane})$, proteins were transferred onto nitrocellulose by standard technique (39). After electroblotting, the nitrocellulose was incubated overnight at $4^{\circ} \mathrm{C}$ in phosphate-buffered saline (PBS, $100 \mathrm{mM} \mathrm{NaCl}, 38 \mathrm{mM} \mathrm{Na}_{2} \mathrm{HPO}_{4}$, $\left.12.5 \mathrm{mM} \mathrm{NaH}_{2} \mathrm{PO}_{4}, \mathrm{pH} 7.4\right)$ containing $5 \%$ bovine serum albumin (Sigma Chemical Co., essentially fatty acid free) and $3 \mathrm{mM} \mathrm{NaN}_{3}$. The nitrocellulose was incubated an additional $30 \mathrm{~min}$ in PBS containing $0.5 \%$ (vol/vol) Tween 20 (PBS-Tween), and the blocked nitrocellulose membrane then was incubated with primary antibody (rabbit antihuman glycoprotein IIb or IIIa) (40) diluted 1:100 in PBS-Tween for $1 \mathrm{~h}$ at $37^{\circ} \mathrm{C}$ with gentle rocking. The membrane was washed three 
times with PBS-Tween and incubated with biotinylated goat antirabbit IgG (Enzo Biochem, New York) diluted 1:1000 in PBS-Tween for $1 \mathrm{~h}$ at $37^{\circ} \mathrm{C}$ with gentle rocking. The membrane was washed three times with PBS-Tween, rinsed once in PBS, and incubated $30 \mathrm{~min}$ at $23^{\circ} \mathrm{C}$ in PBS containing $5 \mathrm{mM}$ trisodium EDTA, $2 \%$ bovine serum albumin, and $0.05 \%$ (vol/vol) Triton X-100. Avidin-acid phosphatase complex (Enzo Biochem) diluted 1:200 in PBS, $5 \mathrm{mM}$ trisodium EDTA was incubated with the membrane $\left(0.08 \mathrm{ml} / \mathrm{cm}^{2}\right)$ for $1 \mathrm{~h}$ at $23^{\circ} \mathrm{C}$ before washing 5 times for 5 min each in $10 \mathrm{mM} \mathrm{K}_{2} \mathrm{HPO}_{4}, 0.5$ $\mathrm{M} \mathrm{NaCl}, 1 \mathrm{mM}$ EDTA, pH 6.5 , containing $2 \%$ bovine serum albumin and $0.5 \%$ Triton X-100. The membrane was rinsed twice $(2 \mathrm{~min}$ per rinse) in a clean dish with $0.2 \mathrm{M}$ acetic acid, $0.2 \mathrm{M}$ sodium acetate, pH 5.8. To detect the complex the membrane was incubated $5 \mathrm{~min}$ with $1 \mathrm{mM}$ Naphthol AS-MX phosphate (Enzo Biochem), $0.2 \mathrm{M}$ sodium acetate, pH 5.8, before adding $1 / 100$ vol of Fast violet B salt (Enzo Biochem) $4 \mathrm{mg} / \mathrm{ml}$ in $0.2 \mathrm{M}$ sodium acetate, pH 5.8. Color development at $23^{\circ} \mathrm{C}$ was first observed after 5-20 min. After 1 to 4 $h$, the membrane was removed from the dye solution, rinsed in tapwater, and air dried. The color of the bands on some nitrocellulose membranes faded upon drying. The addition of water or buffer (neutral or slightly acidic) restored color.

Immunoprecipitation of platelet membrane proteins. This was modified from the techniques of Kessler (41) and Coller et al. (42). Washed platelets were prepared from $150 \mathrm{ml}$ freshly drawn blood and radiolabeled with $\left[{ }^{3} \mathrm{H}\right] \mathrm{NaBH}_{4}$ as detailed above. The platelets $\left(1.4 \times 10^{10} / \mathrm{ml}\right)$ were divided into two $0.7-\mathrm{ml}$ portions and treated with elastase $(80$ $\mathrm{nM})$ or buffer for $3 \mathrm{~min}$ at $37^{\circ} \mathrm{C}$. $\alpha_{1}$-Antitrypsin $(0.2 \mu \mathrm{M})$ was added and the samples centrifuged at $12,000 \mathrm{~g}$ for $30 \mathrm{~s}$.

The precipitates were resuspended in $1.0 \mathrm{ml}$ PBS, $\mathrm{pH} 7.4$, containing $1 \%$ Triton X-100, $1 \mathrm{mM}$ leupeptin (Sigma Chemical Co.) and $3 \mathrm{mM}$ $\mathrm{NaN}_{3}$ at $4^{\circ} \mathrm{C}$ for $15 \mathrm{~min}$ with sonication (three times for $15-20 \mathrm{~s}$, power reading 3.5 with a $4 \frac{1}{2}-$ in. microprobe and microsonicator, Kontes Glass Co., Vineland, NJ). The samples were centrifuged at $5,000 \mathrm{~g}$ for $15 \mathrm{~min}$ at $4^{\circ} \mathrm{C}$, and the supernatant recentrifuged at 40,000 $g$ for 1 h at $4^{\circ} \mathrm{C}$.

Immunobeads $(1.0 \mathrm{ml})$ coated with rabbit anti-mouse immunoglobulin $(10 \mathrm{mg} / \mathrm{ml}$, Bio-Rad Laboratories, Richmond, CA) were washed three times in PBS containing $0.5 \%$ Triton X-100, $0.02 \%$ $\mathrm{NaN}_{3}, 0.1 \%$ bovine serum albumin, pH 8.4 (PBS-Triton), by spinning at $1,500 \mathrm{~g}$ for $2 \mathrm{~min}$ and resuspending in $1.0 \mathrm{ml}$ after each wash. The beads were divided into two $0.5-\mathrm{ml}$ portions and mixed with $1.0 \mathrm{ml}$ of either normal mouse ascites fluid (Cappel Laboratories, Cochranville, PA) diluted 1:1000 in PBS-Tween or dessicated ascites fluid containing monoclonal antiglycoprotein Ib (AP-1, a generous gift of Thomas Kunicki; Blood Center of Southeastern Wisconsin) (43) reconstituted in PBS containing $1 \mathrm{mg} / \mathrm{ml} \mathrm{BSA}$, and then similarly diluted 1:1000 in PBS-Tween.

After incubating for $40 \mathrm{~min}$ at $23^{\circ} \mathrm{C}$ and $10 \mathrm{~min}$ at $37^{\circ} \mathrm{C}$, samples were washed four times in PBS-Triton and resuspended in $0.5 \mathrm{ml}$ buffer. The solubilized platelet proteins $(0.1 \mathrm{ml})$ and the antibody coated Immunobeads $(0.1 \mathrm{ml})$ were incubated $60 \mathrm{~h}$ at $4^{\circ} \mathrm{C}$ with mixing and centrifuged $12,000 \mathrm{~g}$ for $2 \mathrm{~min}$. The pellet was washed three times in PBS-Triton as above. To release the bound antigen, the pellet was mixed with $0.1 \mathrm{ml}$ of a solution consisting of one part 3.3\% SDS, 6 $\mathrm{mM} \mathrm{N}$-ethylmaleimide, and one part $1 \% \mathrm{SDS}, 12.5 \mathrm{mM}$ Tris- $\mathrm{HCl}$, $20 \%$ glycerol, $0.025 \%$ Bromphenol blue, $\mathrm{pH} 6.8$, and heated to $100^{\circ} \mathrm{C}$ for $3 \mathrm{~min}$. Samples were centrifuged at $12,000 \mathrm{~g}$ for $2 \mathrm{~min}$ and the supernatants stored $\left(-70^{\circ} \mathrm{C}\right)$. Samples $(10,000 \mathrm{dpm} / \mathrm{lane})$ were analyzed by electrophoresis as described above.

Immunoisolation of platelet membrane glycoprotein Ib was modified from the technique of McEver et al. (44). Immunobeads were coated with monoclonal antiglycoprotein Ib as detailed above. Solubilized ${ }^{3} \mathrm{H}-$ labeled platelet membrane proteins $(0.5 \mathrm{ml})$, prepared as above, and antibody coated Immunobeads $(0.5 \mathrm{ml})$ were incubated $60 \mathrm{~h}$ at $4^{\circ} \mathrm{C}$ with mixing and centrifuged at $12,000 \mathrm{~g}$ for $2 \mathrm{~min}$. The Immunobeads were washed three times in PBS-Triton before washing in $0.15 \mathrm{M}$ $\mathrm{NaCl}, 0.02 \mathrm{M}$ Tris- $\mathrm{HCl}, 1 \%$ Triton-X 100 ; then $1 \mathrm{M} \mathrm{NaCl}, 1 \%$ Triton

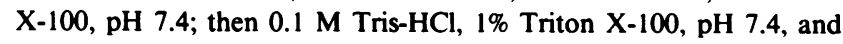

finally in $0.15 \mathrm{M} \mathrm{NaCl}, 0.02 \mathrm{M}$ Tris- $\mathrm{HCl}, 1 \%$ Triton X-100, pH 7.4. Bound protein was eluted with $0.05 \mathrm{M}$ diethylamine, $1 \%$ Triton $\mathrm{X}$ $100, \mathrm{pH}$ 11.5. The eluate was neutralized with $2 \mathrm{M}$ Tris- $\mathrm{HCl}, 1 \%$ Triton X-100, pH 7.4, dialyzed against $0.15 \mathrm{M} \mathrm{NaCl}, 0.02 \mathrm{M}$ Tris$\mathrm{HCl}, 2.5 \mathrm{mM}$ EDTA, and stored at $4^{\circ} \mathrm{C}$. Aliquots were incubated with either elastase $(5 \mathrm{nM})$ or buffer for various times at $37^{\circ} \mathrm{C}$ prior to heating $\left(100^{\circ} \mathrm{C}\right)$ for $3 \mathrm{~min}$ with an equal volume of $0.06 \mathrm{M}$ Tris$\mathrm{HCl}, 2 \%$ SDS, $5 \%$ glycerol, $0.001 \%$ bromphenol blue, and $2 \%$ DTT. All samples were stored $\left(-70^{\circ} \mathrm{C}\right)$ prior to electrophoresis $(10,000$ dpm/lane).

\section{Results}

Elastase inhibition of thrombin-induced platelet aggregation. Elastase inhibited thrombin-induced platelet aggregation in a time- and dose-dependent manner. In Fig. 1, washed platelets $\left(2 \times 10^{8} / \mathrm{ml}\right)$ were stirred with either elastase $(10 \mathrm{nM} ; 30,000$ molecules/platelet) or with buffer for $1 \mathrm{~min}$ at $37^{\circ} \mathrm{C}$. A threshold dose of thrombin ( $1 \mathrm{nM})$ then was added. The elastase-treated platelets failed to aggregate, whereas the buffertreated platelets responded normally. The concentration of elastase chosen was below that documented to appear during blood coagulation (28-140 nM) (3). Although aggregation of elastase-treated platelets did not occur after exposure to thrombin, examination by phase microscopy revealed that shape change had occurred. In subsequent experiments, the inhibition of thrombin-induced platelet aggregation was found to be both time and dose dependent (Fig. 2). Elastase inhibition of ristocetin-mediated agglutination paralleled the inhibition of thrombin stimulation. In contrast, similar concentrations of elastase did not inhibit platelet aggregation by ADP, epinephrine, arachidonic acid, or collagen.

To explore whether the action of elastase was due either to a direct interaction with platelets or to proteolytic inactivation of thrombin, $\alpha_{1}$-antitrypsin was used to inhibit elastase activity. In Fig. 3 (bottom) elastase ( $10 \mathrm{nM})$ was incubated with washed platelets for $1 \mathrm{~min}$ at $37^{\circ} \mathrm{C}$. After inhibition of elastase by addition of $\alpha_{1}$-antitrypsin $(64 \mathrm{nM})$, thrombin $(1 \mathrm{nM})$ was added. Aggregation did not occur. These experiments suggested that elastase inhibited aggregation by acting on the platelet rather than on thrombin. In a separate study (Fig. 3, top tracing) $\alpha_{1}$-antitrypsin (64 $\mathrm{nM}$ ) was added to washed platelets prior to addition of elastase. Elastase was then added and the mixture incubated for $1 \mathrm{~min}\left(37^{\circ} \mathrm{C}\right)$. Subsequent addition of thrombin $(1 \mathrm{nM})$ resulted in aggregation. This study demon-

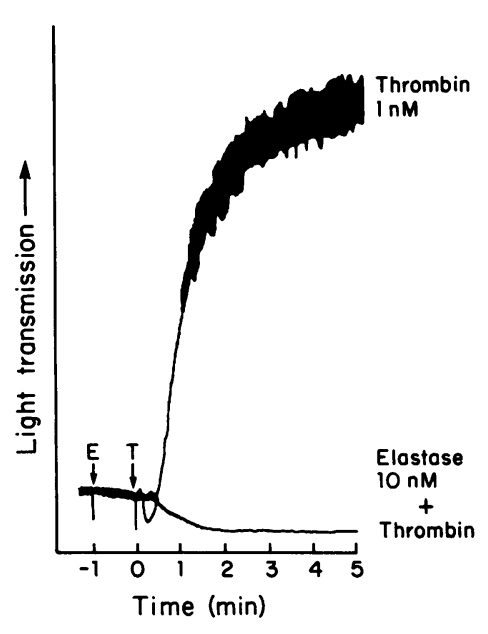

Figure 1. Elastase inhibition of thrombin-induced platelet aggregation. Washed platelets $\left(2 \times 10^{8}\right)$ $\mathrm{ml})$ were stirred with (bottom tracing) or without (top tracing) elastase (10 nM; 3,000 molecules/platelet) for $1 \mathrm{~min}$ at $37^{\circ} \mathrm{C}$. Thrombin ( $1 \mathrm{nM})$ was then added. Aggregation was recorded as an increase in light transmission. 

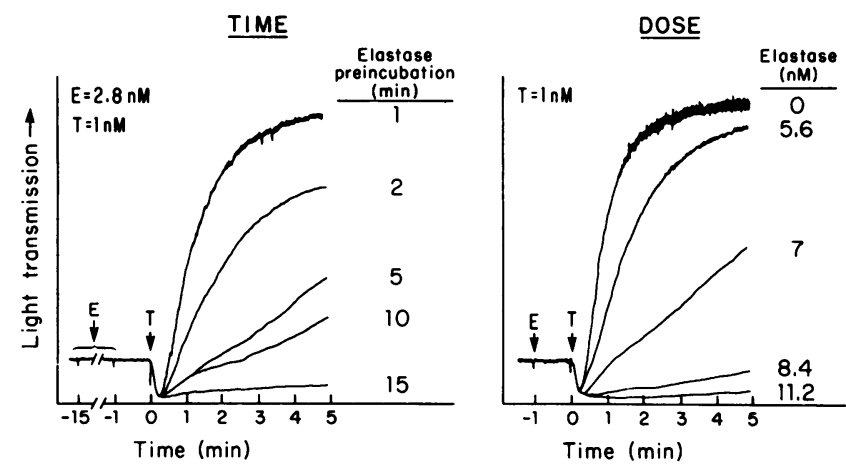

Figure 2. Time- and dose-dependent inhibition of thrombin-induced platelet aggregation by elastase. $(A)$ Time dependence. Washed platelets $\left(2 \times 10^{8} / \mathrm{ml}\right)$ were stirred with elastase (E) $2.8 \mathrm{nM}$ (a lower concentration than in Fig. 1) at $37^{\circ} \mathrm{C}$ for $1-15$ min prior to the addition of a $1 \mathrm{nM}$ threshold dose of thrombin (T). (B) Dose dependence. Washed platelets $\left(2 \times 10^{8} / \mathrm{ml}\right)$ were stirred with elastase $(0-11.2 \mathrm{nM})$ for $1 \mathrm{~min}$ at $37^{\circ} \mathrm{C}$ prior to the addition of thrombin (1 $\mathrm{nM})$. Aggregation was recorded by the increase in light transmission over time. Aggregation study shown is a representative study from four separate time and dose experiments.

strates that an excess of $\alpha_{1}$-antitrypsin can prevent elastasemediated inhibition of thrombin-induced platelet aggregation. Although $\alpha_{1}$-antitrypsin has been reported to inhibit thrombin (45), in concurrent control studies platelet aggregation was not inhibited by mixing similar concentrations of $\alpha_{1}$-antitrypsin with platelets prior to addition of thrombin.

Elastase inhibition of thrombin-induced secretion of $\left[{ }^{14} \mathrm{C}\right]$ serotonin by platelets. Elastase inhibited thrombin-induced $\left[{ }^{14} \mathrm{C}\right]$ serotonin release from platelets. Examples of a standard curve of thrombin-induced serotonin release and the effect of a $1-\min \left(37^{\circ} \mathrm{C}\right)$ incubation of platelets with various concentrations of elastase (0.9-90 $\mathrm{nM})$ prior to thrombin addition are shown in Fig. 4. Compared with untreated platelets, a washed platelet suspension pretreated with elastase was less sensitive to thrombin-induced $\left[{ }^{14} \mathrm{C}\right]$ serotonin secretion. As a result the curve of serotonin release shifted to the right. The concentration of thrombin required to liberate $50 \%$ of maximally releasable $\left[{ }^{14} \mathrm{C}\right]$ serotonin from control platelets was $2.5 \mathrm{nM}$. After platelets were preincubated with elastase $(0.9 \mathrm{nM})$, the concentration of thrombin required was $4 \mathrm{nM}$. Increasing the concentration of elastase resulted in a progressive shift to the right, suggesting that the inhibitory effect of elastase on thrombin-induced

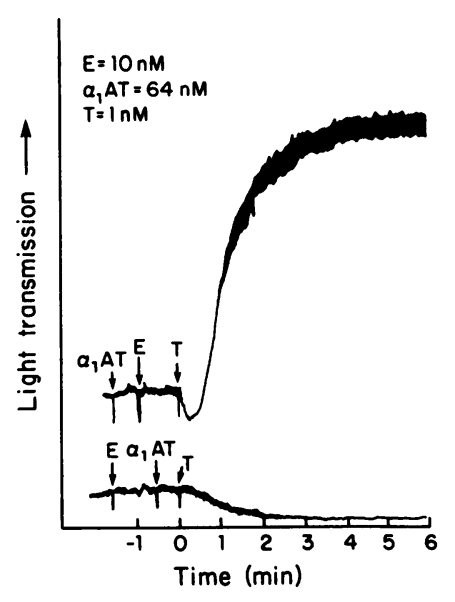

Figure 3. Inhibition of elastase by $\alpha_{1}$-antitrypsin. (top) Washed platelets $\left(2 \times 10^{8} / \mathrm{ml}\right)$ were stirred with $\alpha_{1}$-antitrypsin $(\alpha, \mathrm{AT}) 64 \mathrm{nM}$ for $1 \mathrm{~min}$ at $37^{\circ} \mathrm{C}$. Elastase (E) $10 \mathrm{nM}$ was then added for $\sim 1 \mathrm{~min}$ before the addition of thrombin (T) 1 nM; (bottom) washed platelets were stirred with elastase ( 10 $\mathrm{nM})$ for $\sim 1 \mathrm{~min}$ at $37^{\circ} \mathrm{C}$. $\alpha_{1-}$ Antitrypsin (64 $\mathrm{nM})$ was then added $\sim 1$ min before the addition of thrombin ( $1 \mathrm{nM})$. Aggregation was recorded as the increase in light transmission.

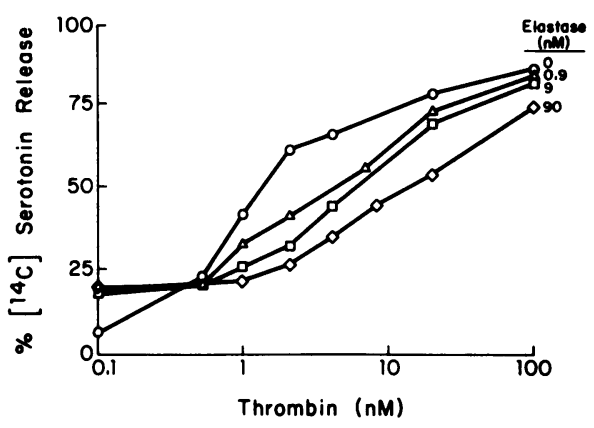

Figure 4. Inhibition of thrombin-induced $\left[{ }^{14} \mathrm{C}\right]$ serotonin release from platelets by elastase. Washed platelets $\left(2 \times 10^{8} / \mathrm{ml}\right)$ containing $\left[{ }^{14} \mathrm{C}\right]$ serotonin were mixed with elastase $(0.9-90 \mathrm{nM})$ or buffer for 1 min at $37^{\circ} \mathrm{C} . \alpha_{1}$-Antitrypsin was added (inhibitor:elastase molar ratio $\geq 1.3: 1$ ) and the platelets were incubated with various concentrations of thrombin as described in Methods. Percent ${ }^{14} \mathrm{C}$ release is plotted as a function of thrombin concentration.

serotonin release was dose dependent. The concentration of thrombin required to liberate $50 \%$ of $\left[{ }^{14} \mathrm{C}\right]$ serotonin from platelets incubated with $9 \mathrm{nM}$ elastase was $6 \mathrm{nM}$; and with 90 $\mathrm{nM}$ elastase, $15 \mathrm{nM}$.

Effect of elastase on the binding of thrombin to platelets. Treatment with concentrations of elastase sufficient to inhibit thrombin-induced platelet aggregation altered the binding of thrombin to platelets (Fig. 5). The Scatchard plot of thrombin binding before elastase treatment (Fig. 5, closed circles) was nonlinear. As analyzed by the method of Munson and Rodbard (34), these findings suggested two classes of binding sites $(F$ ratio test of two-site versus one-site model: $F=22.8 ; P$ $<0.001$ ). Before elastase treatment there were $31 \pm 83$ high affinity receptors per platelet $\left(K_{d}=0.093 \pm 0.054 \mathrm{nM}\right)$ and $1,500 \pm 300$ low affinity receptors $\left(K_{d}=122 \pm 250 \mathrm{nM}\right)$. After elastase treatment (Fig. 5, open circles), the steep portion of the curve is attenuated, and the presence of high affinity binding sites is less apparent. Analyzed as above, there were $5.4 \pm 6.4$ high affinity receptors per platelet $\left(K_{d}=0.042 \pm 0.003\right.$ $\mathrm{nM}$ ) after elastase treatment and $1,100 \pm 4,300$ low affinity receptors $\left(K_{\mathrm{d}}=212 \pm 250 \mathrm{nM}\right)$.

The results of seven experiments of this type are summarized in Table I, demonstrating that the number of high affinity binding sites per platelet was diminished from $31 \pm 10$ before elastase exposure to $12 \pm 13$ after elastase treatment $(P<0.05)$. The $K_{\mathrm{d}}$ for the high affinity receptor was $0.10 \pm .06 \mathrm{nM}$; the decrease in the $K_{\mathrm{d}}$ after elastase treatment was not statistically significant. Neither the number of low affinity thrombin binding sites/platelet $(4,500 \pm 5,100)$ nor the $K_{d}(98 \pm 90 \mathrm{nM})$ was significantly altered by incubation with elastase under these conditions.

In three of the seven thrombin binding experiments summarized in Table I the number of elastase molecules per platelet was approximately $6 \times 10^{3}$ (the number of molecules/ platelet in Fig. 1 was $1.5 \times 10^{4}$ ). Two of the three incubations resulted in a reduction in the number of high affinity receptors $>25 \%$. With an increase in both the ratio of molecules of elastase/platelet to $\sim 2.2 \times 10^{4}$ and in the incubation time to $20 \mathrm{~min}$, all four subsequent determinations resulted in reductions of $>45 \%$ in the number of high affinity receptors per platelet. In two of these four experiments high affinity receptors were no longer detectable after elastase treatment. 


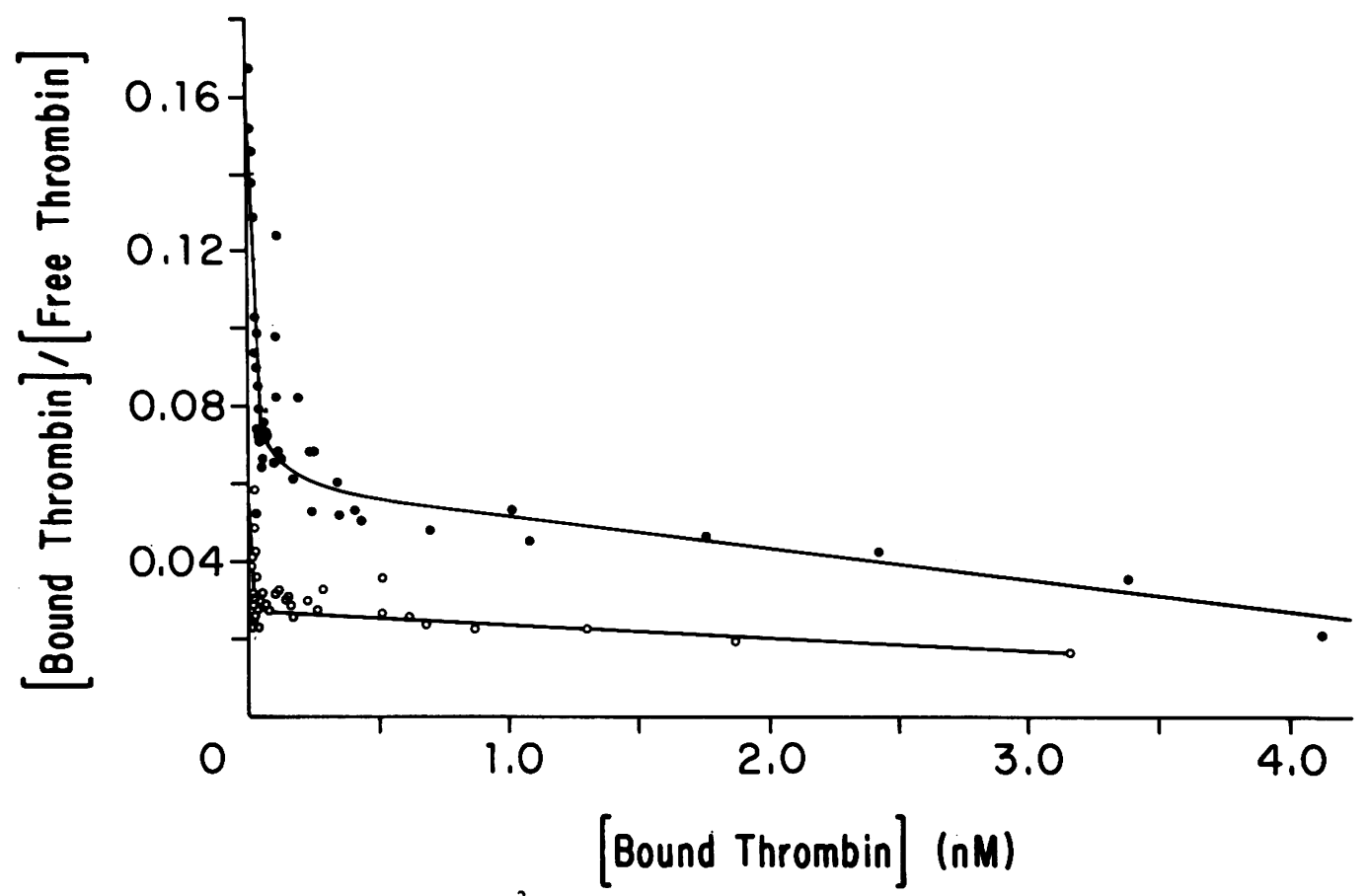

Figure 5. Scatchard plot analyses of the binding of thrombin to normal platelets (๑) and elastase treated platelets $(0)$. Washed platelets (2 $\left.\times 10^{9} / \mathrm{ml}\right)$ were incubated with elastase (74 $\mathrm{nM}$; $2.23 \times 10^{4}$ molecules/ platelet) or buffer for 20 min at $37^{\circ} \mathrm{C}$. After adding $\alpha_{1}$-antitrypsin $(0.3$ $\mu \mathrm{M})$, the platelets were equilibrated for $15 \mathrm{~min}$ at $23^{\circ} \mathrm{C}$, diluted $\left(3 \times 10^{8} /\right.$ $\mathrm{ml})$, and incubated with various concentrations of ${ }^{125}$ I-thrombin (0-200 nM) for $10 \mathrm{~min}$ at $23^{\circ} \mathrm{C}$. Bound and free thrombin were measured as described in the methods. Data points represent uncorrected binding from a single experiment. Lines

were derived from the formula (46) $B=\sum_{n=1}^{2} F R_{n} /\left(F+N_{n}\right)$, where $B$ is the concentration of receptor-bound thrombin, $F$ is the concentration of

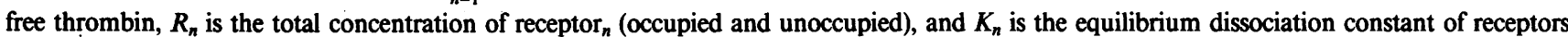
belonging to binding class $\mathrm{n}$. Values for the constants $R_{n}$ and $K_{n}$ are obtained from the Ligand program described in Methods.

Effect of elastase on platelet surface glycoproteins. Human leukocyte elastase $(0.8 \mu \mathrm{M})$ was incubated with washed ${ }^{3} \mathrm{H}$ labeled platelets and the results analyzed after SDS-PAGE by fluorography (Fig. 6) and densitometry. In comparison with untreated platelets (Fig. 6 a), there was a marked difference in platelet surface membrane glycoproteins after treatment with elastase (Fig. $6 b$ ). First, elastase treatment resulted in a decrease in the relative percentage of glycoprotein in the range of $M_{\mathrm{r}}=130,000$ to 150,000 . Proteins in this range include glycoproteins Ib and IIb (47). Concomitant with this was a relative increase in glycoprotein at $M_{\mathrm{r}}=102,000$.

The supernatants from both elastase-treated and untreated platelets were similarly analyzed. Untreated platelets (Fig. $6 c$ ) showed one band at $M_{\mathrm{r}}=131,000$ believed to be glycocalicin (47). Compared with control platelets the supernatant from the elastase-treated platelets (Fig. $6 d$ ) showed new protein bands at approximate molecular weights of $88,000,35,000$, and 29,000. Protein at $M_{\mathrm{r}}=88,000$ is in the region of glyco-

Table 1. Platelet Thrombin Receptors: Effect of Elastase

\begin{tabular}{|c|c|c|c|c|}
\hline \multirow[b]{2}{*}{ Platelets } & \multicolumn{2}{|c|}{ High affinity receptor } & \multicolumn{2}{|c|}{ Low affinity receptor } \\
\hline & Sites/platelet* & $K_{d}$ & Sites/platelet & $\dot{K}_{d}$ \\
\hline & & $n M$ & & $n M$ \\
\hline $\begin{array}{l}\text { Normalł } \\
\text { Elastase }\end{array}$ & $31 \pm 10 \$$ & $0.10 \pm 0.06$ & $4,600 \pm 5,100$ & $98 \pm 90$ \\
\hline treated & $12 \pm 13 \S$ & $0.037 \pm 0.05$ & $3,800 \pm 8,300$ & $77 \pm 96$ \\
\hline
\end{tabular}

* The number of thrombin binding sites/platelet and $K_{d}$ were calculated by analysis of seven binding experiments using the "Ligand" binding program as detailed in Methods. Values are means \pm standard deviation.

$\ddagger$ Platelets $\left(2 \times 10^{9} / \mathrm{ml}\right)$ were treated with $14-74 \mathrm{nM}$ elastase $\left(0.6\right.$ to $2.2 \times 10^{4}$ molecules/platelet) or with buffer alone for $1-20$ minutes at $37^{\circ} \mathrm{C}$.

$\S P<0.05$ by Wilcoxon signed-ranked test. protein $\mathrm{V}(48,49)$. However, the quantity of protein at this molecular weight raises the possibility that at least part of the protein was formed by elastase cleavage of a higher molecular weight glycoprotein precursor.

To explore further the action of elastase on platelet surface glycoproteins, ${ }^{3} \mathrm{H}$-labeled platelets $\left(10^{10} / \mathrm{ml}\right)$ were incubated with elastase ( $50 \mathrm{nM} ; 3,000$ molecules elastase/platelet), a 16 fold lesser concentration than used in Fig. 6. As demonstrated in Fig. 7 (lanes 1-5) the relative quantity of platelet surface glycoprotein at molecular weight 130,000 to 140,000 was markedly reduced within $30 \mathrm{~s}$ of incubation; additional reduction in protein at this molecular weight occurred with prolonged

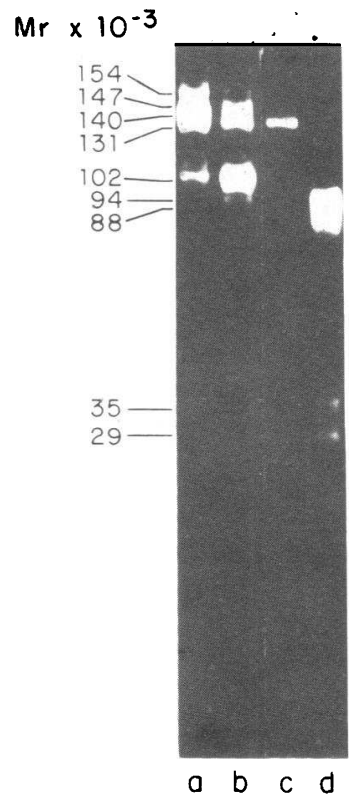

Figure 6. Effect of elastase on platelet surface sialoglycoproteins. ${ }^{3} \mathrm{H}$-surface labeled platelets $\left(2 \times 10^{9} / \mathrm{ml}\right)$ were incubated with or without elastase $(0.8 \mu \mathrm{M})$ for $1 \mathrm{~min}$ at $23^{\circ} \mathrm{C}$. $\alpha_{1}$-Antitrypsin $(4 \mu \mathrm{M})$ was then added to inhibit elastase activity. The platelets were sedimented, the supernatant harvested, and the platelets washed and resuspended in buffer $\left(10^{10} / \mathrm{ml}\right)$. Samples $\left(10^{5} \mathrm{dpm} /\right.$ lane $)$ of the resuspended pellets and supernatants were reduced and analyzed by SDS-PAGE and fluorography. (a) Control platelets not treated with elastase; $(b)$ platelets after treatment with elastase; (c) supernatant from control platelets not treated with elastase; $(d)$ supernatant from elastase-treated platelets. 


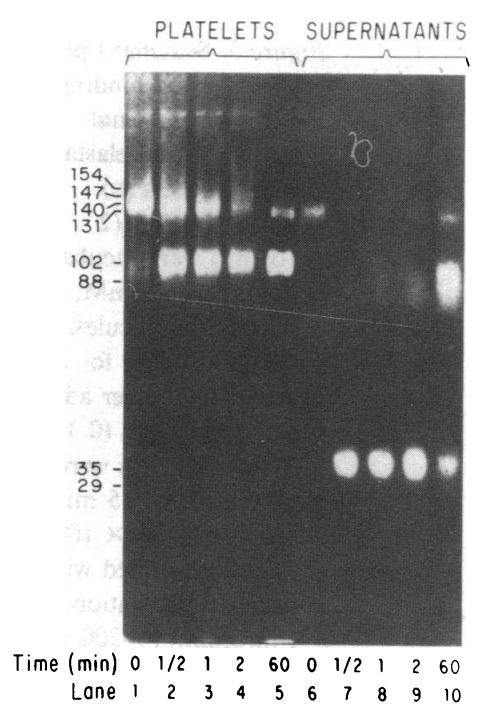

Figure 7. Alteration in glycoprotein structure by elastase as a function of time. Labeled platelets $\left(10^{10} / \mathrm{ml}\right)$ were incubated with elastase $(50 \mathrm{nM})$ at $23^{\circ} \mathrm{C}$. At the times indicated $0.1 \mathrm{ml}$ aliquots were mixed with $\alpha_{1}$-antitrypsin $(1 \mu \mathrm{M})$ to inhibit elastase activity. The platelets were sedimented by centrifugation and the supernatants removed and harvested. The platelets, resuspended in $50 \mu \mathrm{l}$ and the supernatants (each $\sim 80 \mu \mathrm{l}$ ) were mixed with equal volumes of SDS-DTT and heated $100^{\circ} \mathrm{C}$ for $3 \mathrm{~min}$. Samples were electrophoresed $(20,000 \mathrm{dpm} / \mathrm{lane})$ and fluorograms of the platelets and of the corresponding supernatants were obtained by exposure of the gel to the film for 30 days. (Lanes $1-5$ contain $\sim 3 \mu$ of a 1:10 dilution of the platelet pellet after mixing with SDS-DTT. Lanes 5-9 contain $5 \mu \mathrm{l}$ of undiluted platelet supernatant after mixing with SDS-DTT; lane 10 contains $3.5 \mu \mathrm{l}$.)

incubation. Concurrently, there was an increase in the concentration of radiolabeled protein at $M_{\mathrm{r}}=102,000$, suggesting that it is a cleavage product of the $M_{\mathrm{r}}=140,000$ glycoprotein.

The supernatants from platelets after elastase treatment were similarly analyzed (Fig. 7, lanes 6-10). The supernatants prior to elastase treatment showed a single band at $M_{\mathrm{r}}=131,000$ believed to be glycocalicin as in Fig. 6. Within $30 / \mathrm{s}$ of incubation with elastase, protein at $M_{\mathrm{r}}=131,000$ is reduced, and a new band appears at $M_{\mathrm{r}}=35,000$. With longer incubation times, protein is observed at $\sim M_{\mathrm{r}}=88,000$, migrating ahead of the $M_{\mathrm{r}}=102,000$ band observed in lanes 1-5. At $60 \mathrm{~min}$ a faint band at $M_{\mathrm{r}}=29,000$ appears.

In experiments not shown, incubation of platelets with elastase in the presence of EDTA $(1 \mathrm{mM})$ or antipain $(0.2$ $\mathrm{mM}$ ) gave similar results, suggesting that calcium activated protease was not an essential component of this interaction (50).

Immunoenzymatic analysis of the effect of elastase on glycoproteins IIb and IIIa. The effects of elastase on platelet glycoproteins IIb and IIIa were analyzed by Western blot technique followed by immunoenzymatic detection of the glycoprotein with avidin-acid phosphatase complex (Fig. 8). The treatment of platelets with concentrations of elastase sufficient to inhibit thrombin-induced platelet aggregation did not alter the molecular weight or the apparent quantity of platelet glycoproteins IIb and IIIa. Glycoprotein IIb is detected at $M_{\mathrm{r}}=136,000$ (Fig. $8 a$ ). Treatment of platelets with elastase does not alter its molecular weight (Fig. 8 b). Likewise, glycoprotein IIla is apparent at $M_{\mathrm{r}}=106,000$ both before and after elastase treatment (Fig. $8 c, d$ ). The lighter band at $M_{\mathrm{r}}$ $=122,000$ in Fig. $8 c, d$ is in the position that glycoprotein IIIa is found after reduction. Similar analysis of samples after reduction with dithiothreitol confirmed that treatment of platelets with elastase did not alter the electrophoretic mobility of glycoproteins IIb and IIIa (data not shown).

Immunoprecipitation of glycoprotein Ib. Platelets were ra-

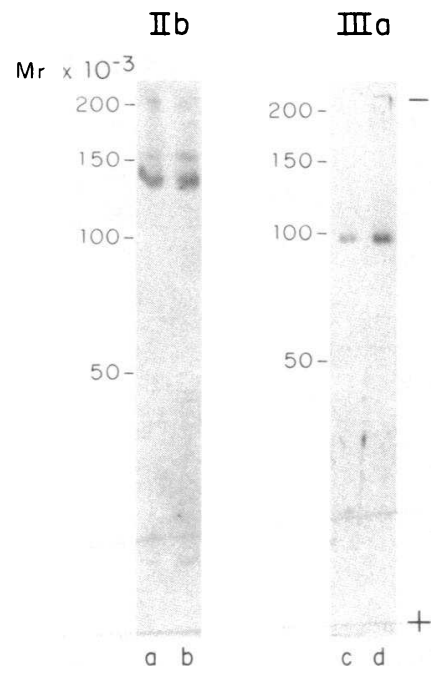

Figure 8. Immunoenzymatic analysis of the effect of elastase on platelet glycoproteins IIb and IIIa. Washed platelets $(8.9$ $\times 10^{9} / \mathrm{ml}$ ) were incubated with or without elastase (80 nM; 5,400 molecules/platelet) for $1 \mathrm{~min}$ at $37^{\circ} \mathrm{C} . \alpha_{1-}$ Antitrypsin $0.2 \mu \mathrm{M}$ then was added to inhibit elastase activity. The platelets were washed, resuspended in buffer, and solubilized in SDS. After electrophoresis and electrotransfer, samples ( $3 \mu \mathrm{g} /$ /ane) were analyzed by immunoenzymatic detection with avidin-acid

phosphatase complex as in Methods. (Left) Detection of glycoprotein IIb in elastase-treated and untreated platelets is shown in lanes $a$ and $b$, respectively. (Right) Detection of glycoprotein IIIa in elastasetreated and untreated platelets is shown in lanes $c$ and $d$, respectively.

diolabeled, solubilized with Triton X-100 and incubated with Immunobeads coated with either AP-1 or normal mouse IgG. Approximately $23 \%$ of the radioactivity from solubilized platelet membranes not pretreated with elastase bound to the AP-1 coated beads. In contrast, after elastase treatment of washed platelets, $0.9 \%$ of the radioactivity from the solubilized platelet membrane bound to the AP-1 coated beads. Control beads coated with normal mouse IgG bound less than $0.5 \%$ of total radioactivity both before and after elastase treatment.

The immunoprecipitate formed by the AP-1 antibody with ${ }^{3} \mathrm{H}$-labeled platelet membranes was analyzed by polyacrylamide gel electrophoresis $(10,000 \mathrm{dpm} / \mathrm{lane})$ after solubilization in SDS. As shown by fluorography, the control bead immunoprecipitate from either solubilized normal platelets (Fig. $9 c$ )

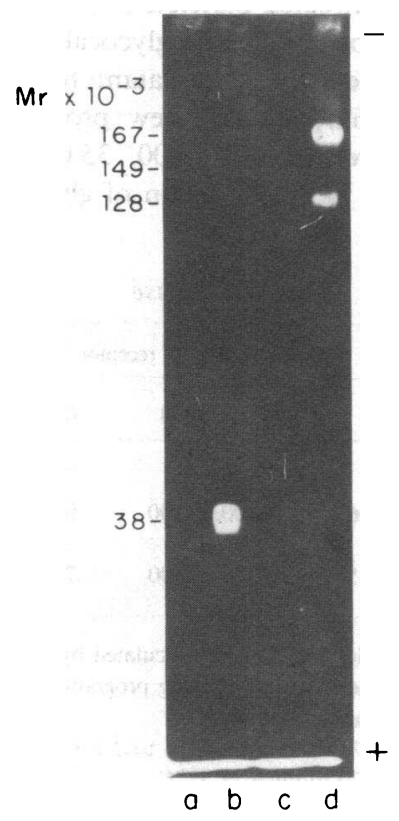

Figure 9. Fluorographic analysis of radiolabeled platelet membrane glycoproteins that bind to AP-1 antibody. ${ }^{3} \mathrm{H}$-surface labeled platelets $\left(1.4 \times 10^{10} / \mathrm{ml}\right)$ were incubated with or without elastase (80 nM) for $3 \mathrm{~min}$ at $37^{\circ} \mathrm{C}$. $\alpha_{1}$-Antitrypsin $(0.2 \mu \mathrm{M})$ then was added. The platelets were sedimented, washed, solubilized in Triton $\mathrm{X}$ 100 , and immunoprecipitated as described in Methods. The immunoprecipitate was solubilized in SDS and electrophoresed $(10,000$ $\mathrm{dpm} /$ lane) in a $9 \%$ polyacrylamide gel. Fluorograms were obtained by exposure of the gel to the film for $7 \mathrm{~d}$. Elastase-treated platelets were immunoprecipitated with beads preincubated with $(a)$ normal mouse ascites or (b) AP-1. Untreated platelets were immunoprecipitated with beads preincubated with $(c)$ normal mouse ascites or (d) AP-1. 
or solubilized elastase-treated platelets (Fig. $9 a$ ) moved with the buffer front. In contrast, the AP-1 immunoprecipitate from untreated platelets (Fig. $9 d$ ) contained two protein bands, a dark band of approximate $M_{\mathrm{r}}=167,000$ and a light band at $M_{\mathrm{r}}=130,000$. These correspond to the reported molecular weights of glycoprotein Ib, 166,000, and glycocalicin, 135,000 (51-53). Proteins of $<20,000 M_{\mathrm{r}}$ migrated with the buffer front so that the intensely reactive band of $M_{\mathrm{r}} \sim 20,000$ reported by Coller et al. (42) was not observed. After treatment with elastase (Fig. $9 b$ ), the relative intensity of the bands at $M_{\mathrm{r}} 167,000$ and 130,000 was reduced. Concomitant with this was the appearance of a protein band at $M_{\mathrm{r}} \sim 35,000$, corresponding to the $M_{\mathrm{r}}=35,000$ band found in the supernatant of elastase-treated platelets. That this peptide contains the antigenic site for the AP-1 monoclonal antibody and is not merely adhering nonspecifically to the AP-1 coated beads remains to be proven.

These studies demonstrate that treatment of whole platelets with elastase results in the degradation of glycoprotein Ib.

Effect of elastase on glycoprotein Ib. Platelet membrane glycoprotein was immunopurified with Immunobeads coated with the AP-1 anti-glycoprotein Ib antibody. Human leukocyte elastase $(5 \mathrm{nM})$ was incubated with immunopurified, ${ }^{3} \mathrm{H}$ labeled glycoprotein and the mixtures were analyzed by SDSPAGE after reduction with dithiothreitol. As shown by fluorography (Fig. 10), the molecular weight of the glycoprotein immunoisolate prior to elastase treatment was $\sim 140,000$. Upon incubation with elastase for $0.5 \mathrm{~min}$, the relative intensity of the band at 140,000 was reduced and a new band appeared at $M_{\mathrm{r}} \sim 94,000$. After one min, most of the radioactivity was found in the $M_{\mathrm{r}} \sim 94,000$ band. No additional degradation was observed with incubation for up to $60 \mathrm{~min}$ (Fig. 10, lanes $a-e$ ). In the control experiment (Fig. 10, lanes $f-j$ ), incubation of the immunoisolate in the absence of elastase did not result in the formation of a lower molecular weight peptide.

These experiments demonstrated that elastase-mediated proteolysis of the $M_{\mathrm{r}}=140,000$ glycoprotein resulted in the formation of a $M_{\mathrm{r}} \sim 94,000$ cleavage product. On SDS-PAGE

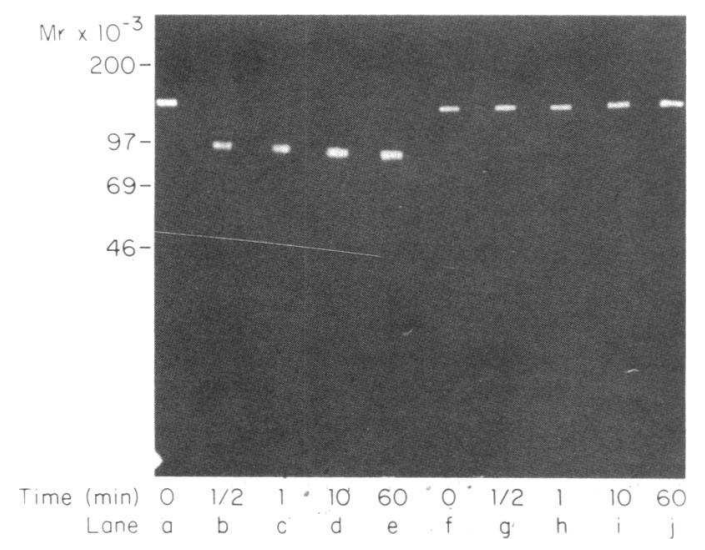

Figure 10. Effect of elastase on platelet glycoprotein Ib. Glycoprotein Ib was immunoprecipitated and eluted as described in Methods. The isolated glycoprotein was incubated for various times with $5 \mathrm{nM}$ elastase (lanes $a-e$ ) or with buffer (lanes $f-j$ ) at $37^{\circ} \mathrm{C}$ prior to heating at $100^{\circ} \mathrm{C}$ for $3 \mathrm{~min}$ with an equal volume of $0.06 \mathrm{M}$ Tris- $\mathrm{HCl}, 2 \%$ SDS, $5 \%$ glycerol, $0.001 \%$ Bromphenol blue, and $2 \%$ DTT. After electrophoresis in a 9\% polyacrylamide gel, fluorograms were obtained by exposure of the gel to the film for $7 \mathrm{~d}$. this peptide comigrated with the $M_{\mathrm{r}} \sim 102,000$ glycopeptide found in elastase-treated platelets (Fig. $6 d$ ), and it migrated more slowly than the $M_{\mathrm{r}}=88,000$ glycopeptide appearing in the supernatant of elastase-treated platelets (gel not shown). These findings suggested that elastase-mediated proteolysis of membrane-bound glycoprotein Ib resulted in formation of a $M_{\mathrm{r}}=94,000$ to 102,000 membrane-associated glycopeptide (Figs. 6, 7, and 10).

Glycoprotein V has a molecular weight of 68,000 to 85,000 (48, 49), raising the possibility that a portion of the $M_{\mathrm{r}}$ $=88,000$ glycopeptide appearing in the supernatant of elastasetreated platelets is glyoprotein V. However, immunoprecipitation studies similar to those above using anti-glycoprotein $\mathbf{V}$ antibody (the kind gift of Dr. David Phillips, Gladstone Foundation Laboratories, San Francisco, CA) (54), demonstrated that elastase treatment did not increase the concentration of glycoprotein $\mathrm{V}$ in platelet supernatants (data not shown).

\section{Discussion}

These studies demonstrate that physiologic concentrations of human leukocyte elastase inhibit thrombin-induced platelet aggregation in a time- and dose-dependent manner. Leukocyte elastase also inhibits ristocetin-induced platelet agglutination and the release of $\left[{ }^{14} \mathrm{C}\right]$ serotonin from platelets. This loss of functional activity is associated with $(a)$ a reduction in the number of high affinity thrombin binding sites per platelet and $(b)$ the proteolysis of platelet glycoprotein Ib.

The low concentration of elastase used to demonstrate inhibition of thrombin-induced platelet aggregation in this study indicates that platelets are highly susceptible to elastase and suggests that these findings are of physiologic relevance. As blood coagulates, polymorphonuclear leukocytes degranulate and release elastase $(2,3)$. Several potentially toxic reactive oxygen species also can be released by degranulated leukocytes (55). $\alpha_{1}$-Antitrypsin, the major plasma inhibitor of elastase, is particularly susceptible to oxidants that can react with the methionine at the reactive center of the inhibitor, thus inactivating its protease-inhibiting activity (10). In a cell contact system Campbell et al. (56) demonstrated that $\alpha_{1}$-antitrypsin inhibited about $80 \%$ of PMN-derived proteolytic activity. Although PMN-derived oxidants did not potentiate elastasemediated proteolysis in this system, Weiss and Regiani (57) showed that concentrations of $\alpha_{1}$-antitrypsin less than $250 \mu \mathrm{g} /$ $\mathrm{ml}$ can be inhibited by a PMN-mediated $\mathrm{H}_{2} \mathrm{O}_{2}$-dependent mechanism. Additionally, Matheson et al. (58) demonstrated that oxidation of $\alpha_{1}$-antitrypsin by myeloperoxidase is optimized at acidic $\mathrm{pH}$ (6.2) such as might be found in an area of thrombosis or inflammation. Conditions present during coagulation might thus facilitate the elastase-mediated proteolysis of platelets as detailed in this study.

The interaction of physiologic concentrations of elastase with platelets is rapid. At an elastase concentration of $50 \mathrm{nM}$ (3,000 elastase molecules/platelet), major quantities of glycoproteins Ib were degraded within $60 \mathrm{~s}$. This correlates with functional studies detailing loss of thrombin responsiveness within this time interval when similar elastase concentrations are used. The finding that glycoprotein Ib is affected by elastase treatment remains compatible with the hypothesis that thrombin might interact with glycoprotein Ib (59-62).

Elastase treatment of glycoprotein immunopurified with antiglycoprotein $\mathrm{Ib}$ antibody produced a peptide with the same 
electrophoretic mobility as the $M_{\mathrm{r}} \sim 102,000$ glycopeptide on the surface of elastase-treated platelets, suggesting that it is a glycoprotein $\mathrm{Ib}$ fragment. However, the origin of the $M_{\mathrm{r}}$ $=88,000$ protein in the supernatant of elastase-treated platelets remains unknown. The difference in the molecular weights of these two peptides is similar to that between the $\alpha$-chain of glycoprotein $\left.\mathrm{Ib} M_{\mathrm{r}}=143,000\right)(51,52)$ and glycocalicin $\left(M_{\mathrm{r}}\right.$ $=135,000)(47,53)$. This raises the possibility that the $M_{\mathrm{r}}$ $=88,000$ peptide might result from elastase-mediated cleavage of glycocalicin. Proof of this hypothesis requires further experimental studies.

As previously reported $(30,63-65)$, analysis of thrombinplatelet binding kinetics demonstrates both high and low affinity thrombin binding sites. The number of low affinity binding sites and the $K_{d}$ reported in this study $(4,600 \pm 5,100$ sites/platelet, $K_{d}=98 \pm 90 \mathrm{nM}$ ) is compatible with the findings of the above authors. However, using computer analysis we have found both the number of high affinity sites per platelet $(31 \pm 10)$ and the $K_{d}(0.10 \pm 0.06)$ to be less than the values previously published (290 to 1,500 sites/platelet; $K_{d}=0.2$ to $3.2 \mathrm{nM})$. We attribute these differences strictly to a more accurate resolution of kinetic constants by the Ligand program for fitting multiple binding site data (34), which was not available to the above investigators. (In studies not shown, analysis using the technique of Chamness and McGuire (66) revealed two classes of binding sites, 340 sites with a $K_{d}$ of $\sim 1.6 \mathrm{nM}$ and 14,000 sites with a $K_{\mathrm{d}}$ of $\sim 180 \mathrm{nM}$, values similar to those reported for the high and low affinity sites.) It appears then that accurate resolution of kinetic constants for the high affinity thrombin receptor by linear regression and extrapolation of the Scatchard plot results in a 10-fold higher value compared to mathematical resolution of the same data using the Ligand program.

A criterion for defining "specific" binding of thrombin to platelets is that it is correlated with physiologic effects (30). Both platelet secretion and platelet aggregation occur at thrombin concentration of 0.1 to $1 \mathrm{nM}$ (Figs. 1 and 4). From thrombin binding studies (Fig. 5) it can be calculated that this range of concentrations encompasses the steep portion of the thrombin binding curve. (An added thrombin concentration of about $1 \mathrm{nM}$ corresponds approximately to a bound/free ratio of 0.10 and to a bound thrombin concentration of 0.1 $\mathrm{nM}$. At a platelet concentration of $2 \times 10^{9} / \mathrm{ml}$, this is equivalent to 30 molecules thrombin/platelet). Approximately 30 thrombin molecules binding per platelet will thus maximize platelet secretion. This suggests that the high affinity sites also are the specific receptors for both the aggregation and secretion reactions. As noted by others (30) it remains possible that the binding of additional thrombin molecules per platelet may produce other as yet unidentified effects on the platelet.

\section{Acknowledgments}

This study could not have been accomplished without the excellent editorial assistance of Ms. Nancy Shayne. Dr. Thomas Detwiler and Eli McGowan kindly provided us with their methodologies for radiolabeling platelets and thrombin. The advice of Drs. Peter Harpel, Lawrence L. K. Leung, Aaron Marcus, Eric Jaffe, and Ralph Nachman is most gratefully acknowledged.

This study was supported by U.S. Public Health Service grants H118828 (Specialized Center of Research in Thrombosis) and R01 HL32166, a grant from the New York Community Trust, National Cancer
Institute grant CA08746, National Heart, Lung, and Blood Institute grant 13160 , and the Dorothy Rosenbloom Foundation. Dr. Levin is the recipient of a National Institutes of Health Clinical Investigator Award (5K08 HL-00748).

\section{References}

1. Ohlsson, K., and I. Olsson. 1977. The extracellular release of granulocyte collagenase and elastase during phagocytosis and inflammatory processes. Scand. J. Haematol. 19:145-152.

2. Plow, E. F. 1981. Leukocyte elastase release during blood coagulation: A potential mechanism for activation of the alternate pathway. J. Clin. Invest. 69:564-572.

3. Brower, M. S., and P. C. Harpel. 1983. $\alpha_{1}$-Antitrypsin-human leukocyte elastase complexes in blood: Quantification by an enzymelinked differential antibody immunosorbent assay and comparison with $\alpha_{2}$-plasmin inhibitor-plasmin complexes. Blood. 61:842-849.

4. Egbring, R., W. Schmidt, G. Fuchs, and K. Havemann. 1977. Demonstration of granulocytic proteases in plasma of patients with acute leukemia and sypticemia with coagulation defects. Blood. 49: 219-231.

5. Jochum, M., J. Witte, H. Schiessler, H. K. Selbmann, G. Ruckdeschl, and H. Fritz. 1981. Clotting and other plasma factors in experimental endotoxemia: Inhibition of degradation by exogenous proteinase inhibitors. Eur. Surg. Res. 13:152-168.

6. Jochum, M., S. Lander, N. Heimburger, and H. Fritz. 1981. Effects of human granulocytic elastase on isolated human antithrombin III. Hoppe-Seyler Z. Physiol. Chem. 362:103-112.

7. Brower, M. S., and P. C. Harpel. 1982. Proteolytic cleavage and inactivation of $\alpha_{2}$-plasmin inhibitor and $\mathrm{Cl}$ inactivator by human polymorphonuclear leukocyte elastase. J. Biol. Chem. 257:9849-9854.

8. Ohlsson, K., and I. Olsson. 1974. Neutral proteases of human granulocytes. III. Interaction between human granulocyte elastase and plasma protease inhibitors. Scand. J. Clin. Invest. 34:349-355.

9. Carp, H., and A. Janoff. 1979. In vitro suppression of serum elastase-inhibitory capacity by reactive oxygen species generated by phagocytosing polymorphonuclear leukocytes. J. Clin. Invest. 63:793797.

10. Johnson, D., and J. Travis. 1979. The oxidative inactivation of human $\alpha$-1-proteinase inhibitor. Further evidence for methionine at the reactive center. J. Biol. Chem. 254:4022-4026.

11. Henry, R. L. 1965. Leukocytes and thrombosis. Thromb. Diath. Haemorrh. 13:35-46.

12. Mitchell, J. R. A., and C. J. Schwartz. 1965. Arterial diseases. Blackwell Scientific Publications, Ltd., Oxford. pp. 201-331.

13. Wester, J., J. J. Sixma, J. J. Geuze, and H. Heijnen. 1979. Morphology of the hemostatic plug in human skin wounds. Transformation of the plug. Lab. Invest. 41:182-192.

14. Marcus, A. J., M. J. Broekman, L. B. Safier, H. L. Ullman, N. Islam, C. N. Serhan, L. E. Rutherford, H. M. Korchak, and G. Weissman. 1982. Formation of leukotrienes and other hydroxy acids during platelet-neutrophil interactions in vivo. Biochem. Biophys. Res. Commun. 109:130-137.

15. Maclouf, J., B. Fruteau de Laclos, and P. Borgeat. 1982. Stimulation of leukotriene biosynthesis in human blood leukocytes by platelet derived 12-hydroperoxy-icosatetraenoic acid. Proc. Natl. Acad. Sci. USA. 79:6042-6046.

16. Goetzl, E. J. 1980. Mediators of immediate hypersensitivity derived from arachidonic acid. N. Engl. J. Med. 3:822-825.

17. Serhan, C. N., A. Radin, J. E. Smolen, H. Korchak, B. Samuelsson, and G. Weissman. 1982. Leukotriene $B_{4}$ is a complete secretagogue in human neutrophils: A kinetic analysis. Biochem. Biophys. Res. Commun. 107:1006-1012.

18. Lonky, S. A., J. Marsh, and H. Wohl. 1978. Stimulation of human granulocyte elastase by platelet factor 4 and heparin. Biochem. Biophys. Res. Commun. 85:1113-1118. 
19. Lonky, S. A., and H. Wohl. 1981. Stimulation of human leukocyte elastase by platelet factor 4 . Physiologic, morphology, and biochemical effects on hamster lungs in vitro. J. Clin. Invest. 67:817826.

20. Lonky, S. A., and H. Wohl. 1983. Regulation of elastolysis of insoluble elastin by lysine-rich ligands, anionic detergents, and ionic strength. Biochemistry. 22:3714-3720.

21. Baugh, R. J., and J. Travis. 1976. Human granule elastase: Rapid isolation and characterization. Biochemistry. 15:836-841.

22. Weber, K., J. R. Pringle, and M. Osborn. 1972. Measurement of molecular weights by electrophoresis on SDS-acrylamide gels. Methods Enzymol. 26:3-27.

23. Powers, J. C., and B. F. Gupton. 1977. Reaction of serine proteases with aza-amino acid and aza-peptide derivatives. Methods Enzymol. 46:208-216.

24. Pannell, R., D. Johnson, and J. Travis. 1974. Isolation and properties of human plasma $\alpha_{1}$-proteinase inhibitor. Biochemistry. 13: 5439-5445.

25. Mustard, J. F., D. W. Perry, N. G. Ardlie, and M. A. Packham. 1972. Preparation of suspensions of washed platelets from humans. Br. J. Haematol. 22:193-204.

26. Weksler, B. B., A. A. Marcus, and E. A. Jaffe. 1977. Synthesis of prostaglandin $\mathrm{I}_{2}$ (prostacyclin) by cultured human and bovine endothelial cells. Proc. Natl. Acad. Sci. USA. 74:3922-3926.

27. Weskler, B. B., C. Ley, and E. A. Jaffe. 1978. Stimulation of endothelial cell prostacyclin production by thrombin, trypsin, and the ionophore A 23187. J. Clin. Invest. 62:923-930.

28. Levin, R. I., B. B. Weksler, and E. A. Jaffe. 1982. The interaction of sodium nitroprusside with human endothelial cells and platelets: Nitroprusside and prostacyclin synergistically inhibit platelet function. Circulation. 66:1299-1307.

29. Baenziger, N. L., M. Dillender, and P. W. Majerus. 1977. Cultured human skin fibroblasts and arterial cells produce a labile platelet-inhibitory prostaglandin. Biochem. Biophys. Res. Commun. 78:294-301.

30. Martin, B. M., W. W. Wasiewski, J. W. Fenton II, and T. C. Detweiler. 1976. Equilibrium binding of thrombin to platelets. Biochemistry. 15:4886-4893.

31. Kirchoff, B. R. J., C. Vermeer, and H. C. Hemker. 1978. The determination of prothrombin using synthetic chromogenic substrates: choice of a suitable activator. Thromb. Res. 13:219-232.

32. Chase, T., and E. Shaw. 1970. Titration of trypsin, plasmin, and thrombin with p-nitrophenyl-p'-guanidinobenzoate $\mathrm{HCl}$. Methods Enzymol. 19:20-27.

33. Peersche, E. I., M. B. Zucker, R. A. Grant, J. J. Egan, and M. M. Johnson. 1980. Correlation between fibrinogen binding to human platelets and platelet aggregability. Blood. 55:841-847.

34. Munson, P. J., and D. Robard. 1980. Ligand: A versatile computerized approach for characterization of ligand-binding systems. Anal. Biochem. 107:220-239.

35. Steck, T. L., and G. Dawson. 1974. Topographical distribution of complex carbohydrates in the erythrocyte membrane. J. Biol. Chem. 249:2135-2142.

36. Tam, S. W., J. W. Fenton II, and T. C. Detweiler. 1980. Platelet thrombin receptors: Binding of $\alpha$-thrombin is coupled to signal generation by a chymotrypsin-sensitive mechanism. J. Biol. Chem. 255:6626-6632.

37. Laemmli, U. K. 1970. Cleavage of structural proteins during the assembly of the head of bacteriophage $\mathrm{T}_{4}$. Nature (Lond.). 227: 680-684.

38. Kinoshita, T., R. Nachman, and R. Minick. 1979. Isolation of human platelet plasma membranes with polylysine beads. J. Biol. Chem. 82:688-696.

39. Burnette, W. N. 1981. "Western Blotting": Electrophoretic transfer of proteins form sodium dodecyl sulfate-polyacrylamide gels to unmodified nitrocellulose and radiographic detection with antibody and radiolabelled protein A. Anal. Biochem. 112:195-203.

40. Nachman, R. L., and L. L. K. Leung. 1982. Complex formation of platelet membrane glycoproteins IIb and IIla with fibrinogen. $J$. Clin. Invest. 69:263-269.

41. Kessler, S. W. 1975. Rapid isolation of antigens from cells with a staphylococcal protein A-antibody absorbent: Parameters of the interaction of antibody-antigen complexes with protein A. J. Immunol. 115:1617-1624.

42. Coller, B. S., E. I. Peerschke, L. E. Scudder, and C. A. Sullivan. 1983. Studies with a murine monoclonal antibody that abolishes ristocetin-induced binding of von Willebrand factor to platelets: additional evidence in support of GPIb as a platelet receptor for von Willebrand factor. Blood. 61:99-110.

43. Montgomery, R. R., T. J. Kunicki, C. Travis, D. Pidard, and M. Corcoran. 1983. Diagnosis of Bernard-Soulier Syndrome and Glangmann's thromblasthemia with a monoclonal assay on whole blood. J. Clin. Invest. 71:385-389.

44. McEver, R. P., N. L. Baenziger, and P. W. Majerus. 1980. Isolation and quantitation of the platelet membrane glycoprotein deficient in thrombasthenia using a monoclonal hybridoma antibody. J. Clin. Invest. 66:1311-1318.

45. Downing, M. R., J. W. Bloom, and K. G. Mann. 1978. Comparison of the inhibition of thrombin by three plasma protease inhibitors. Biochemistry. 17:2649-2653.

46. Donner, D. B., J. Casandei, L. Hartstein, D. Martin, and M. Sonenberg. 1980. Characterization of the slowly dissociable human growth hormone binding component of isolated rat hepatocytes. Biochemistry. 19:3295-3300.

47. McGregor, J. L., K. J. Clemetson, E. James, T. Greenland, and M. Dechavanne. 1979. Identification of human platelet glycoproteins in SDS-polyacrylamide gels using ${ }^{125}$ I-labelled lectins. Thromb. Res. 15:825-832.

48. Phillips, D. R., and P. P. Agin. 1977. Platelet plasma membrane glycoprotein identification of a proteolytic substrate for thrombin. Biochem. Biophys. Res. Commun. 75:940-947.

49. Mosher, D. F., A. Vaheri, J. J. Choate, and C. G. Gahmberg 1979. Action of thrombin on surface glycoproteins of human platelets. Blood. 53:437-445.

50. Yoshida, N., B. Weksler, and R. Nachman. 1983. Purification of human platelet calcium-activated protease. Effect on platelet calciumactivated protease. Effect on platelet and endothelial function. J. Biol. Chem. 258:7168-7174.

51. Phillips, D. R. 1980. An evaluation of membrane glycoproteins in platelet adhesion and aggregation. Prog. Hemostasis Thromb. 5:81110.

52. Clemetson, K. J., H. Y. Naim, and E. F. Luscher. 1981. Relationship between glycocalicin and glycoprotein Ib of human platelets. Proc. Natl. Acad. Sci. USA. 78:2712-2716.

53. Okumura, T., C. Lombart, and G. A. Jamieson. 1976. Platelet glycocalicin II. Purification and characterization. J. Biol. Chem. 251: 5950-5955.

54. Berndt, M. C., and D. R. Phillips. 1981. Purification and preliminary physiochemical characterization of human platelet membrane glycoprotein V. J. Biol. Chem. 256:59-65.

55. Weiss, S. J., P. K. Rustage, and A. F. Lo Buglio. 1978. Human granulocyte generation of hydroxyl radical. J. Exp. Med. 147:316-323.

56. Campbell, E. J., R. M. Senior, J. A. McDonald, D. L. Cox, J. M. Greco, and J. A. Landis. 1982. Proteolysis by neutrophils: Relative importance of cell-substrate contact and oxidative inactivation of proteinase inhibitors in vivo. J. Clin. Invest. 70:845-852.

57. Weiss, S. J., and S. Regiani. 1984. Neutrophils degrade subendothelial matrices in the presence of alpha-1-proteinase inhibitor. Cooperative use of lysosomal proteinase and oxygen metabolites. $J$. Clin. Invest. 73:1297-1303.

58. Matheson, N. R., P. S. Wong, M. Schuyler, and J. Travis. 
1981. Enzymatic interaction of human $\alpha_{1}$-proteinase inhibitor by neutrophil myeloperoxidase. Biochem. Biophys. Res. Commun. 88: 402-409.

59. Tollefsen, D. M., and P. W. Majerus. 1976. Evidence for a single class of thrombin-binding sites on human platelets. Biochemistry. 15:2144-2149.

60. Okumura, T., and G. A. Jamieson. 1976. Platelet glycocalcin: A single receptor for platelet aggregation induced by thrombin or ristocetin. Thromb. Res. 8:701-706.

61. Okumura, T., M. Hasitz, and G. A. Jamieson. 1978. Platelet glycocalicin. Interaction with thrombin and role as thrombin receptor of the platelet surface. J. Biol. Chem. 253:3435-3443.

62. Ganguly, P., and N. L. Gould. 1979. Thrombin receptors of human platelets: Thrombin binding and antithrombin properties of glycoprotein I. Br. J. Haematol. 42:137-145.

63. Tollefsen, D. M., J. R. Feagler, and P. W. Majerus. 1974. The binding of thrombin to the surface of human platelets. J. Biol. Chem. 249:2646-2651.

64. Shuman, M. A., D. M. Tollefsen, and P. W. Majerus. 1976. The binding of human bovine thrombin to human platelets. Blood. 47:43-54.

65. Jamieson, G. A., and T. Okumura. 1978. Reduced thrombin binding and aggregation of Bernard-Soulier platelets. J. Clin. Invest. 61:861-864.

66. Chamness, G. C., and W. L. McGuire. 1975. Scatchard plots: Common errors in correction and interpretation. Steroids. 26:538542. 